\title{
Exploration and Research of Counselor Assistants in College Student Work
}

\author{
Ling Duan ${ }^{1}$, Haiyan Yao ${ }^{1}$ \\ ${ }^{1}$ Xijing University, Xi'an, Shaanxi Province, 710123
}

Keywords: Exploration, Research, Counselor Assistants, College Student Work

\begin{abstract}
The implementation of counselor assistant work in colleges and universities helps freshmen adapt to college study and life as soon as possible, improves the relationship between students, reduces the work pressure of counselors and class teachers, and promotes the improvement of student management quality. Therefore, it is necessary to do a good job in selecting, cultivating, managing, and safeguarding counselor assistants, inspiring them to exercise themselves and serve their classmates while studying, and to play the role of assistants and class teachers.
\end{abstract}

\section{Introduction}

Counselor assistants refer to the selection of appropriate outstanding students among senior students in colleges, assisting counselors to manage lower grade students, and adopting a counselor assistant to correspond to a class fixed contact system, providing a new means for students. The implementation of counselor assistant work, in addition to helping solve the problem of increasingly complicated student management and insufficient number of counselors, can give full play to the role of students' self-management, self-education and self-service, and improve the quality of personnel training [1]. College counselors are an important force in college students' ideological and political education. Under the new situation, counselors face many challenges. How to adhere to the scientific development concept and explore new ways and methods of college students' ideological and political education with the spirit of reform and innovation is to strengthen and improve the system of counselor assistants. In this regard, we adhere to the important subject of ideological and political education for college students. To this end, we adhere to the student-centered approach, based on the actual work of the college students, try to implement the student counselor assistant system, select senior students as fresh counselor assistants, and assist the work of full-time counselors. Hence, plenty of work should be done to strengthen the education, management and services of new students and improve the overall quality of students.

\section{The Basic Connotation of Student Counselor Assistant}

The student counselor assistant is the link between freshmen and the relevant departments of the school and the counselors. It is the assistant of the counselor and the teacher. It is the first "leader" the direct manager of the freshman class. Because of the particularity of his identity and the importance and complexity of his work, he must have the following qualifications as a student counselor assistant: In terms of quality, he must love the motherland, love the Party, love the school, and establish a sense of serving the students wholeheartedly. In terms of work ability, he should possess strong organizational operation ability, management coordination ability, communication ability, emergency response ability, and insight prediction ability. In terms of work attitude, he must maintain a passion for work and persevere, focus on teaching and lead by example, and be responsible. Be responsible for "four responsible", that is, responsible for new students, school leaders, counselors and teachers [2].

The main duties of the student counselor assistant are as follows. First, timely and accurately communicate the various notices and opinions of the school and the teachers to the new students, and cooperate with the various freshmen's work that the school and the teacher have published; Second, keep abreast of the new students' learning, life, thoughts, psychology, etc., and feedback to the counselor in a timely manner; Third, help the new students solve various difficulties and guide 
them to adapt to the study and life of the university; Fourth, establish a new class organization to guide them to carry out class work.

The student counselor assistant has a special status and its positioning is multi-faceted. For one thing, the assistant is just a student. Learning is a natural duty, no matter what kind of activity it is, no matter what role it plays, learning can never be discarded. For another, the identity of counselor assistant is to assistant and provide counseling for the new students. The assistant is the first "teacher" of freshmen in the university, the "leader" of their university life, their psychological "regulator", and they are a trustworthy and dependent senior.

\section{The Practical Significance of Implementing the Assistant System of Student Counselors}

Students are the main body of education. The implementation of the student counselor assistant system, mobilizing the students' strength, and exerting the students' initiative in their education, management and service can effectively enhance the pertinence and effectiveness of the students' ideological and political education work[3].

The first year of college is a very important turning point for college students. Students' strong sense of study and life will be cultivated. There is a large space for activities and a large number of exercise platforms in the university. The competition among students is more intense. In addition to academic achievements, there are also practical knowledge, stylistic expertise, social skills, and organizational talents. College students should realize the care of parents and teachers from the middle school stage, and learn to be a person, work, study and coexist independently after university. From the realization of the university goal to the establishment of new goals, from the middle school leader to the university students, college students need to learn a lot and overcome difficulties with the help and guidance of counselors. Once the new grade has been formed, the establishment of its organizational system and management system, the familiarization and understanding of counselors and students will come into shape. The counselor is responsible for all aspects of the students, the work is trivial and complicated, and it is difficult to cover everything. By training senior students as assistants, counselors will obtain an in-depth understanding of freshmen, get closer to new students, give direct and meticulous guidance to new students. Meanwhile, counselor assisstants, acting as a bridge, link counselors and freshmen. They help counselors to grasp the new ideological dynamics in a timely manner.

Since the university is a comprehensive place, teaching, research and life of teachers are far apart. The direct communication with students is limited. That's why it is impossible to give students more guidance and help in professional learning. The assistants' timely help is without doubt good for the new students to familiarize themselves with the characteristics and methods of professional learning as soon as possible, solve the difficulties and problems in learning, and deepen professional cognition.

It is conducive to promoting the improvement of students' comprehensive quality, comprehensively implementing the party's education policy, adhering to the principle of educating people, moral education first, implementing quality education, improving the level of education modernization, and training socialist builders who are fully developed in morality, intelligence and beauty. It is the fundamental task of higher education institutions to succeed the education of the people. With the development of society and the advancement of science and technology, society has higher and higher requirements for students' comprehensive quality. From the perspective of the law of educational development and the practice of student management, the growth and development of students, whether it is the acquisition of knowledge, the formation of abilities, or the improvement of quality, must be achieved through students' own subjective efforts and active practice. Allowing senior students to serve as counselor assistants for new students can enhance students' subjective awareness, play the main role of students in the process of educating people, improve their ability of "self-education, self-management, self-service" and promote their growth faster [4] . 


\section{Measures to Strengthen the Construction of Counselor Assistants}

As for the implementation of the counselor assistant system, the key is to build a team of counselors. To make them a useful supplement to the ideological and political education work team, and to play their role in the education, management and service of new students, we must cultivate, manage and use this team well.

The system has the normative and authoritative characteristics. To train, manage, and use the counselor assistant team, you must use the system as a guarantee, use the system to standardize the selection and training of counselor assistants, motivate the assistants of the counselors, and guide and standardize the counselor assistants to work, examine and evaluate their job performance. Therefore, in the implementation of the counselor assistant system, it is necessary to establish and improve the management and work systems of the counselor assistants. For example, the selection and training system of counselor assistants, the appointment system, the work system, the evaluation system and job duties. Only with a scientific, fully implemented and perfect system can we play the role of this team.

Since the assistants of the counselors are excellent students in the upper grades, they should play the role of "teachers". In terms of knowledge reserve and ability literacy, the requirements for "teachers" are higher than those of student cadres. Let the counselor assistants find the right position, be prepared, competent, and play its due role. Pre-job training is the foundation. To this end, we implement a qualification certificate system: organize counselor assistants training classes in the first half of each year, and train senior students who are qualified and willing to undertake counselor assistant work through lectures and seminars. These all can improve counselors' duties and working mechanisms, applied psychology, work methods and work skills, writing skills, practical management knowledge, interpersonal and communication skills, professional development status and prospects, career planning theory, etc. that is, to obtain a qualification certificate. Then, based on the number of new students, we should comprehensively examine the academic performance and ideological performance of the students who have obtained the qualifications, and determine the candidates for appointment.

Students who are assistants to counselors have strong abilities. To make them work together and work toward the same goal, they must be effectively managed. Only when management is in place can the relevant system be implemented. Appointed counselor assistants, equipped according to small classes, form a group according to the middle class, a large class with a team leader, and implement team management. The team leader is responsible for convening a regular meeting every week, communicating the work situation, sharing experience and understanding, and learning from each other. The freshmen counselor organizes a counselor assistant work report meeting every month to understand the work of the counselor assistant, guide the work, examine the work performance, and implement effective management. The party branch of the counselor assistant is responsible for the teachers' participation in the work report meeting, to understand the work and performance of the assistants of the counselors, and to provide opinions for the branch to discuss their participation in the party. When the counselor assistant branch collects opinions from the public, it also collects opinions from the freshmen counselors and freshmen representatives. When conditions permit, the freshmen counselors or freshmen representatives attend the meeting to discuss the assistants or the corrective questions, thus strengthening the assistants to the counselors.

Incentives can mobilize people's potential enthusiasm, maintain a constant motivation, and achieve their stated goals. Counselor assistants have strong work ability and excellent academic performance. After being a counselor assistant, it is a big challenge for students who have heavy academic tasks to achieve academic achievement, work performance and ability to exercise. They have to face the test of perseverance and ability. Give certain affirmation, appreciation and motivation to their work, counselor assistants can stimulate their potential, scientifically manage time, pay attention to efficiency, work hard, and play their due role [5].

There are various ways and means of motivation, including spiritual incentives, material incentives, emotional incentives and honorary incentives. Only by choosing the right incentives can we form effective incentives. For students who are assistants to counselors, their purpose as 
assistants for counselors is not to obtain direct material benefits, but to improve overall quality and enhance employment competitiveness, and to become the pillars of the future development of their careers. Therefore, when motivating them, we must pay attention to spiritual incentives and honor incentives. If they are given timely guidance in their work, it will be helpful for them to complete each task well and meet their self-realization and self-development needs. For activists who are outstanding in performance and in line with the conditions of party members, the party branch absorbs the party in time according to the development procedures and realizes their desire to pursue political progress. At the end of the term, the organization selects excellent counselor assistants and publicizes them. Approved counselor assistants are treated the same as student cadres, and appropriate points are added during the comprehensive assessment of the school year.

\section{Conclusion}

The counselor assistant system is an effective means to strengthen students' ideological and political education and management work. The counselor assistant is a useful supplement to the students' ideological and political education work. However, how to further clarify the orientation and functions of counselor assistants, improve their working mechanisms, and better play their role, we need to constantly explore in practice. In short, the ideological and political work of college students has a long way to go. As long as we persist in seeking truth from facts, starting from the reality of college reform and development, we will actively explore new ideas, new methods, and new ways to do a good job in ideological and political work under the new situation. The ideological and political work of college students will certainly be able to shoulder the heavy responsibilities entrusted by history.

\section{References}

[1] Jin Min. Practice and Thinking of College Staff as Part-time Counselors [J]. School Party Construction and Ideological Education, 2008, (11). 45

[2] Hu Fang. Investigation and Countermeasure Analysis of College Students' Ideological and Political Status [J]. Journal of Guizhou University of Technology, 2009, (4). 63

[3] Fan Xingye. On the Personal Charm of Counselors [J]. Business (Education Economics Research), 2008, (6). 72

[4] Zhou Ya. The Conception of the Assistant System of Student Party Members in Vocational Colleges [J]. Science and Technology Entrepreneurship Monthly, 2011, (18): 100-104.

[5] Zhang Xinxian. Application of the Senior Supreme System in the Management of College Students [J]. Journal of Qiqihar Vocational College, 2010, (3): 79-81. 